\title{
Giant cell tumor arising from anterior arc of rib
}

\author{
Shah S. ${ }^{1}$, Rao R. ${ }^{2}$, Roplekar P.M. ${ }^{3}$ \\ ${ }^{1}$ Dr. Sagar Shah, Resident, ${ }^{2}$ Dr. Rajiv Rao, Professor, ${ }^{3}$ Dr. Prakash M. Roplekar, Professor and Head, all authors are \\ affiliated with Department of Pathology, D. Y. Patil University, School of Medicine, Nerul, Navi Mumbai, Maharashtra, \\ India.
}

Address for Correspondence: Dr. Sagar Shah, Email: sagaryshah@gmail.com

\begin{abstract}
Giant cell tumor of bone also known as Osteoclastoma has only recently been included in the diagnostic purview of the cytopathologist. It is a benign but locally aggressive neoplasm most commonly found in the epiphysis or metaphysealepiphyseal region of long bones. Rarely, it can occur on the ribs, usually on the posterior aspect i.e. head and tubercle of the ribs. We, therefore report a case of giant cell tumor arising from the anterior arc of the rib, diagnosed on fine needle aspiration cytology.
\end{abstract}

\section{Introduction}

Giant cell tumors constitute about $5-8 \%$ of all bone tumors with most cases occurring in the $3^{\text {rd }}$ and $4^{\text {th }}$ decades of life with a slight female predominance [1]. Giant cell tumors of bone usually arise in the epiphyseal region of the long bones. The rib is a rare site, with most cases occurring on the posterior arc i.e. head and tubercle of ribs. In this report, we describe a case of giant cell tumor of bone originating from the anterior arc of the rib.

\section{Case Report}

A 35 year old female was admitted in the surgery department with the chief complaints of swelling over right hypochondriac region since 3 years, which was gradually increasing in size. It was associated with pain on lifting weights. The mass measured $4 \times 4 \mathrm{~cm}$, was firm and attached to the chest wall. The overlying skin was normal (Figure 1). The patient had no pulmonary symptoms. All hematological and biochemical investigations were within normal limits.

An ultrasonography of the swelling was performed which revealed a heterogeneously hypoechoic lesion in the muscular plane occupying the intercostal space and bulging outwards along with cortical breach of the underlying rib. The abdominal radiograph revealed a large, ill defined mass growing anteriorly

The patient underwent fine needle aspiration cytology. The cytologic smears were cellular and showed cohesive clusters of mononuclear spindle cells having well defined borders, ovoid nuclei with bland chromatin, prominent nucleoli and moderate amount of eosinophilic cytoplasm.

Numerous osteoclastic giant cells were seen at the periphery of these clusters along with few scattered mitotic figures. No significant atypia was noted (Figure 2).

A final diagnosis of giant cell tumor of rib was made.

Though the patient was admitted in our hospital, she refused surgery, got herself discharged and eventually was lost to follow up.

Manuscript received: $14^{\text {th }}$ March 2017

Reviewed: $24^{\text {th }}$ March 2017

Author Corrected: $3^{\text {rd }}$ April 2017

Accepted for Publication: $11^{\text {th }}$ April 2017 


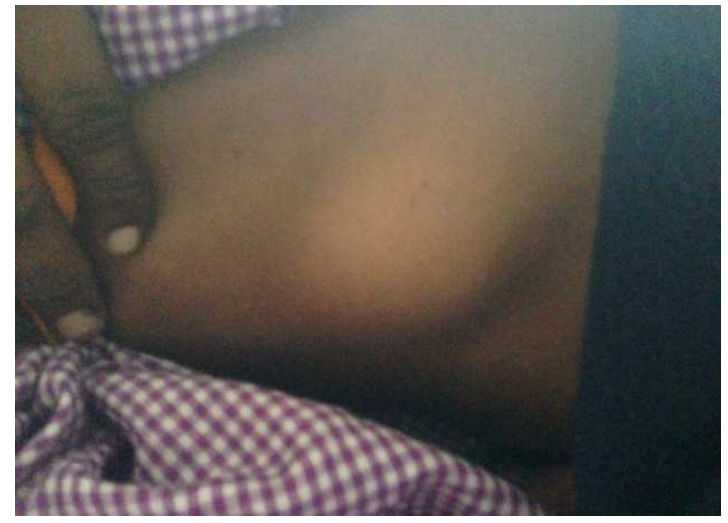

Figure-1: Swelling over anterior arc of rib

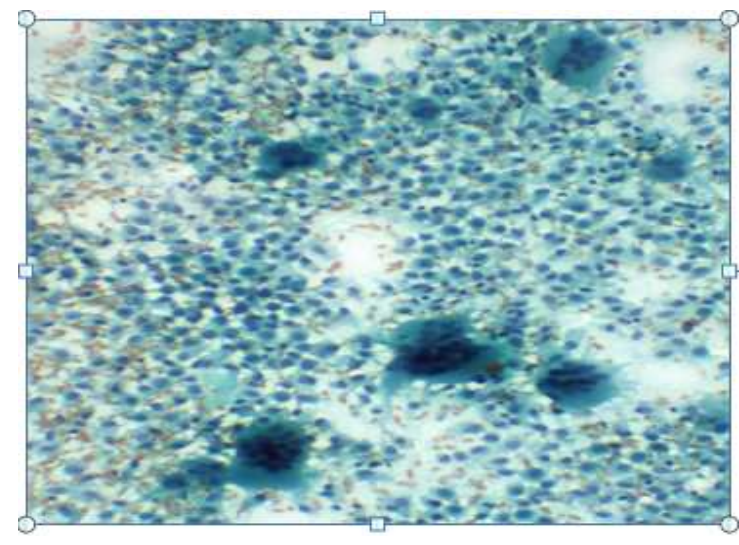

Figure-2: Cohesive clusters of spindle cells surrounded by multinucleated giant cells (Pap, 40x)

\section{Discussion}

Giant cell tumor of bone is a rare neoplasm, which accounts for about $4-5 \%$ of all primary bone tumors [2]. Some categorize it into 3 grades, grade I (Conventional tumor), grade II (Borderline tumor) and grade III (Malignant tumor) [1].

It most commonly affects the epiphysis of long bones, $60 \%$ arising around the knee joint [3]. Only few cases of giant cell tumor of the ribs have been reported, most of them involving the posterior rib. Very few cases of giant cell tumor involving the anterior arc of the rib as seen in our case have been reported in literature.

A variety of lesions may mimic giant cell tumors and it could be difficult to separate it from aneurysmal bone cyst, malignant fibrous histiocytoma, chondroblastoma, brown tumor and giant cell rich osteosarcoma [4].

In aneurysmal bone cyst, aspirates are hemorrhagic with sparse cellularity and comprise of scattered osteoclastic giant cells, fibroblasts and hemosiderin laden macrophages. Malignant fibrous histiocytoma and giant cell rich osteosarcoma are characterized by nuclear anaplasia and mitotic figures.

In chondroblastoma, chondroid matrix and plump spindle shaped mononuclear cell component along with occasional osteoclastic giant cells are present. In brown tumors, spindly mononuclear cells, osteoclasts and macrophages are present along with characteristic biochemical findings of hyperthyroidism. Even though osteoclastic giant cells were present in our case, there were no hemosiderin laden macrophages, nuclear atypia or chondroid matrix. Also our patient showed normal biochemical tests, thus ruling out other differential diagnoses. Others tumors common in the anterior part of the rib are Ewing's sarcoma, chondrosarcoma and infective osteomyelitis [2].

Malignant change in giant cell tumors is usually uncommon. However, excision is desirable as $10 \%$ of the giant cell tumors can undergo malignant transformation [3]. Giant cell tumors are locally aggressive but distant metastasis is uncommon. Even if metastasis does occur, it rarely proves fatal. Regular follow up is mandatory.

\section{Conclusion}

Diagnosis of giant cell tumor, even though rare, should be suspected given the particular clinical scenario and cytologic findings. In a developing country like India with limited resources, fine needle aspiration cytology has proved to be a simple, fast, inexpensive procedure and an important diagnostic tool even for rare presentations.

Funding: Nil, Conflict of interest: None initiated, Permission from IRB: Yes

\section{References}

1. Khan AR, Mir BA. Finac-(giant cell. Tujimor of bone a study of 13 cases. JK-Practitioner. 2003;10(3): 236-8.

2. Kalra GD, Agarwal A. Rare gigantic giant cell tumor of anterior ribs in a young lady. Indian J Surg Oncol. 2014 Dec;5(4):300-2. doi: 10.1007/s13193-014-0352-1. Epub 2014 Sep 10. 
3. Sharma A, Armstrong AE. Giant cell tumor of rib arising anteriorly as a large inframammary mass: a case report and review of the literature. Case Rep Med. 2012; 2012:850509. doi: 10.1155/2012/850509. Epub 2012 Nov 27.

4. Manjunatha H, Ramaswamy A, Kumar BS. Aggressive giant cell tumor of the anterior arc of the rib. J Cytol. 2012 Jan;29(1):51-3. doi: 10.4103/09709371.93224.
5. Jain M, Aiyer HM, Singh M, Narula M. Fine-needle aspiration diagnosis of giant cell tumour of bone presenting at unusual sites. Diagnostic cytopathology. 2002 Dec 1;27(6):375-8.

6. Shin JS, Lee IS, Kim A, Kim BH. Giant cell tumor originating from the anterior arc of the rib. $\mathrm{J}$ Korean Med. Sci. 2002 Dec; 17 (6): 849-51.

\section{How to cite this article?}

Shah S, Rao R, Roplekar P.M. Giant cell tumor arising from anterior arc of rib. Trop J Path Micro 2017;3(2):139141.doi: 10.17511/jopm.2017.i2.12. 